\title{
JOHN STUART MILL: AUTONOMIA, INDIVIDUALIDADE E CIVILIZAÇÃO
}

\author{
Raquel Isaac*, Mauro Cardoso Simões.
}

\begin{abstract}
Resumo
A presente pesquisa tem como objetivo apresentar o filósofo mais significativo do liberalismo inglês do séc. XIX, John Stuart Mill, para então, analisar algumas particularidades de seu pensamento filosófico. O trabalho procurará, assim, investigar a preocupação milleana com as noções de liberdade e individualidade, para então, aplicar e comparar estes conceitos às sociedades tradicionais e àquelas em que há clara presença de um Estado, a partir da interlocução das ideias promulgadas por Mill e de contemporâneos que se dedicaram a estudar as sociedades tradicionais.
\end{abstract}

\section{Palavras-chave: \\ Autonomia, individualidade, civilização.}

\section{Introdução}

A globalização tem direcionado os homens a uma homogeneização; a esmagadora e sufocante opinião das massas dita com afinco as regras e comportamentos sociais e reprova qualquer forma de autenticidade, ao tentar refrear o homem enquanto "eu irredutível", livre de toda externalidade, de desenvolver sua individualidade.

É, pois, em meio a tantas discussões e diferentes correntes filosóficas emergindo em sua época, que o filósofo inglês, John Stuart Mill, defenderá a liberdade e a individualidade como motores indispensáveis à salvação da humanidade. A opinião pública é, para Mill, um obstáculo à formação da individualidade humana e ao florescimento da originalidade e justifica sua necessidade pela constatação de que foi precisamente a experimentação humana e seus resultados, que nos permitiram chegar até aqui. Assim, é justamente na mitigação da originalidade onde Mill vê o principal perigo de nossa época.

Como propósito da presente pesquisa, ampliaremos, então, os conceitos milleanos para a relação sociedadesociedade, a fim de examinar e defender a necessidade de diferentes formas de abordar a existência como garantia da evolução da humanidade.

\section{Resultados e Discussão}

$\mathrm{Na}$ tentativa de entender como a intervenção da sociedade afeta a construção do indivíduo, John Stuart Mill, se preocupou em discutir os conceitos de autonomia, liberdade e individualidade. Para ele, a liberdade individual é absoluta, não cabendo aos homens exercer qualquer forma de poder sobre o outro, contra sua vontade, se não for para impedir dano a terceiros. Defende que são justamente os "homens de gênio" que impedem a humanidade de estagnar na "mediocridade coletiva" e que a individualidade e a

autonomia não são apenas imprescindíveis para alcançar a felicidade e realização próprias, como são, também, peça chave para o progresso da humanidade. A ampliação dos conceitos milleanos para a relação sociedade-sociedade, permitiu o debate sobre a legitimidade da intervenção de sociedades globais na liberdade de ser de pequenas comunidades tribais.
Como sociedades capazes de sobreviver durante milhares de anos, seu estilo de vida não deve ser tratado como obsoleto ou ineficaz na era global. Ao contrário, muitos dos traços da vida tradicional ainda estão presentes no "mundo moderno": o atual estágio de desenvolvimento em que se encontra a modernidade só pôde ser alcançado justamente pelo acúmulo das experiências anteriormente vividas, somadas ao amadurecimento de suas faculdades. Para sustentação dessas afirmações, foram analisadas três importantes comunidades. A dos gregos, a dos Emberá e os intitulados "minimalistas". São grupos que, seja pelo contato com outras civilizações ou pela reflexão sobre seu próprio modelo de vida, buscaram a evolução humana sem deixar de viver segundo sua própria moral. A partir delas, foi possível constatar que enquanto a humanidade for imperfeita, a individualidade de cada uma delas deve ser preservada. Não há razão para que um grupo determine seu modo de viver como o ideal, quando há tantos outros de realidades e perspectivas diferentes do seu. Deve procurar discuti-las e contestalas antes de qualquer intervenção na liberdade do outro.

\section{Conclusões}

O princípio da individualidade proposta por Mill é sinônimo de escolha, de autoafirmação e de criação. Não contém qualquer informação sobre o tipo de valores e modos de vida que se deve adotar, não possuindo a forma de um princípio de ação e de vida criativa, mas seria um princípio a que cada indivíduo tem a liberdade de atribuir o conteúdo que melhor atende às suas „preferências' e necessidades. Não faz distinção ou enaltece uma sociedade em detrimento das demais. É antes, um discurso sobre a garantia da liberdade para todo e qualquer indivíduo e sociedade que deseje viver conforme seu próprio modo de ver a vida. Um discurso pela preservação de sujeitos conscientes de si mesmos, livres, universais e peças chave de nossa evolução.

SIMÕES, Mauro Cardoso. John Stuart Mill \& A Liberdade. RJ: Jorge Zahar Editor,2008

MILL, John Stuart. Sobre a Liberdade. Tradução: Ari R. Tank Brito. São Paulo: Hedra $\quad$ LTDA, 2011. DIAMOND, Jared. The world until yesterday . Great Britain: Allen Lane, 2012. 